\title{
Proteinuria in Children with Febrile Illnesses
}

\author{
MELVIN I. MARKS, ^ PETER N. MCLAINE, and KEITH N. DRUMMOND \\ From Renal Laboratory, McGill University-Montreal Children's Hospital Research Institute
}

\begin{abstract}
Marks, M. I., McLaine, P. N., and Drummond, K. N. (1970). Archives of Disease in Childhood, 45, 250. Proteinuria in children with febrile illnesses. Transient proteinuria in the absence of underlying renal disease was detected in 11 of 198 children $(5.6 \%)$ admitted to hospital with an acute febrile illness. Proteinuria was noted only in children whose fever was higher than $38.4{ }^{\circ} \mathrm{C}$. Selectivity studies on the protein excreted showed patterns ranging from poorly to highly selective. Initial screening for proteinuria using a dipstick method revealed a high incidence of false positives, of which only about $30 \%$ could be confirmed by the sulphosalicylic acid method.

The pathophysiology of transient proteinuria in febrile patients is not understood; a number of mechanisms are probably involved. Since fever was the only detected feature common to each of the patients with proteinuria, it seems unlikely that the specific aetiology of the fever is a factor of importance in the pathogenesis of the proteinuria.
\end{abstract}

The association of proteinuria with fever was first described in the 19th century (Gerhardt, 1869). Though its significance and pathogenesis are not understood, it is generally considered to be a benign and transient phenomenon (Schwartz and Kassirer, 1963).

It was once thought possible to predict the seriousness of a given renal disease on the basis of the quantity of protein excreted (King and Gronbeck, 1952). It is now recognized, however, that in certain serious renal disorders the degree of proteinuria may be minimal (Hardwicke and Soothill, 1967; Pollak et al., 1958). Conversely, as in certain forms of the nephrotic syndrome, a good prognosis may be seen even with massive proteinuria (Canadian Medical Association Journal, 1967; Arneil, 1967).

The purpose of this study was to determine the incidence and clinical significance of proteinuria in febrile children. An attempt was made to characterize the selectivity pattern of the urinary proteins by means of differential protein clearances.

\section{Materials and Methods}

Included in the study were 198 febrile children admitted to the Montreal Children's and Alexandra

Received 12 August 1969.

^Present address: Department of Pediatrics, University of Colorado, Denver, Colorado, U.S.A.
Hospitals from January to March 1968. Fever was $\square$ defined as a temperature rise above $37 \cdot 2{ }^{\circ} \mathrm{C}$. orally or $37 \cdot 8^{\circ} \mathrm{C}$. rectally. Renal disease was excluded on the basis of the physical examination and normal urinalyses either at the time of the fever or subsequently.

Using a dipstick* method an initial screening test for $\stackrel{\mathbb{D}}{\mathbb{2}}$ proteinuria was done on all febrile children upon $\overrightarrow{\bar{O}}$ admission to hospital and at 4-hourly intervals during 3 the febrile period. If a reading of $30 \mathrm{mg} . / 100 \mathrm{ml}$. or more was obtained, a sulphosalicylic acid method (Cipriani and Brophy, 1943) was then used to exclude any false positives detected by the dipstick method and을 to quantitate the proteinuria. The quantitative sulpho-? salicylic acid method for urine protein measurement was 3 done in the following manner. $0.5 \mathrm{ml}$. $3 \%$ sulphosalicylic acid was added to an equal volume of urine. Using the same volumes of urine and distilled water as a blank, the turbidity of the sulphosalicylic acid precipi-을 tate was measured at $540 \mu$ in a Coleman Junior Spectrophotometer. The protein concentration was determinedo by using a standardized curve prepared with solutions of known protein concentration. All measurements $\mathrm{N}$ were done by the same person; no patient received any drug or radiopaque dye known to give false positives by this method. The accuracy of this method has beencw shown to compare favourably with a micro-Kjeldahl method (Cipriani and Brophy, 1943; Looney ando Walsh, 1939), with immunoassay methods (Rennie and Keen, 1967), and is similar to that used by Harrison et $\stackrel{\oplus}{+}$ al. (1968). Urines with a protein concentration of $30 \mathrm{mg} . / 100 \mathrm{ml}$. or more as determined by the sulpho-o salicylic acid method were concentrated 10-20 times in $\overrightarrow{\mathbb{D}}$

*Albustix-Ames Co. of Canada Ltd., Toronto, Ontario. 
dialysis tubing ${ }^{\star}$ by osmotic activity against a sucrose medium for use in the selectivity studies of the protein excreted (McFarlane, 1964). Blood was taken within 24 hours of urine sampling and the serum removed.

The serum protein concentration was measured by the biuret method (Gornall, Bardawill, and David, 1949). Using a modification of the methods of Cameron and White (1965) and MacLean and Robson (1967) selectivity studies were done on the protein excreted. Immunodiffusion platest containing antibodies to human transferrin ( $M W$ 88,000), immunoglobulin G (IgG, MW 150,000), and $\alpha_{2}$-macroglobulin (MW 840,000) were used to determine the urine : serum $(U / S)$ ratios for each of these proteins. To calculate the relative clearances of these proteins the $U / S$ ratios of both IgG and $\alpha_{2}$-macroglobulin were expressed as a percentage of the $U / S$ ratio of transferrin $(100 \%)$ and plotted on a logarithmic scale against the respective molecular weights of these proteins. From the slope of the line obtained the angle theta $(\theta)$ was measured (Joachim et al., 1964). This angle reflects the degree of selectivity of the proteinuria; values in excess of $67^{\circ}$ are indicative of high selectivity whereas those less than $54^{\circ}$ represent poor selectivity (Joachim et al., 1964).

To determine whether the proteinuria was persistent, a 24-hour urine collection was obtained on all patients with proteinuria within two weeks of the febrile episode.

\section{Results}

The clinical diagnoses included bacterial and viral respiratory infections $(30 \%)$, viral exanthemata $(14 \%)$, gastro-enteritis $(8 \%)$, infectious hepatitis (5\%), and viral stomatitis (4\%). Miscellaneous causes including patients with the Riley Day syndrome, leukaemia, septicaemia, osteomyelitis mumps, cervical adenitis, and mastoiditis accounted for $27 \%$ of cases. The cause of the fever was unknown in $12 \%$.

^Dialyzer Tubing, Seamless Cellulose-Fisher Scientific Co. Ltd., Montreal, Quebec.

†Immunoplate-Hyland Division Travenol Laboratories Inc., Los Angeles, California.

TABLE I

Sex Distribution, Ages, and Incidence of Proteinuria by Dipstick and Sulphosalicylic Acid Tests in 198 Patients

\begin{tabular}{l|c|c|c|c|c}
\hline & $\begin{array}{c}\text { No. } \\
\text { of } \\
\text { Patients }\end{array}$ & $\begin{array}{c}\text { No. } \\
\text { of } \\
\text { Tests }\end{array}$ & $\begin{array}{l}\text { Dipstick } \\
\text { Positive }\end{array}$ & $\begin{array}{c}\text { Confirmed } \\
\text { Positive } \\
(30 \mathrm{mg} . / \\
100 \mathrm{ml} . \\
\text { or more })\end{array}$ & Ages \\
\hline $\begin{array}{l}\text { Male } \\
\text { Female }\end{array}$ & 102 & 142 & 17 & 5 & $\begin{array}{c}2 \mathrm{mth} .-16 \mathrm{yr} . \\
4 \mathrm{mth}-17 \mathrm{yr} .\end{array}$ \\
\hline Total & 198 & 275 & 37 & 11 & $\begin{array}{r}\text { Mean =4.5 } \\
\text { yr. }\end{array}$ \\
\hline
\end{tabular}

^By sulphosalicylic acid method.
As shown in Table I, 275 urines from 198 patients were tested. 37 urine samples were positive by the dipstick method; these specimens were from different subjects. Proteinuria was confirmed by the sulphosalicyclic acid method in 11 patients. Thus, the incidence of proteinuria in febrile children was 11 out of 198 , or $5.6 \%$. The incidence was similar in both sexes. The majority of false positives detected by the dipstick method contained less than $10 \mathrm{mg}$. protein per $100 \mathrm{ml}$. by the sulphosalicylic acid technique.

Proteinuria was not detected in 96 urines tested from patients whose temperatures ranged from $37 \cdot 2-38 \cdot 3{ }^{\circ} \mathrm{C}$. (see Table II). The 24 -hour urine specimens obtained from the 11 patients with proteinuria within two weeks of the initial febrile episode each contained less than $40 \mathrm{mg}$. protein.

TABLE II

Incidence of Proteinuria in Relation to Temperature Range

\begin{tabular}{l|c|c}
\hline $\begin{array}{c}\text { Temperature } \\
\left({ }^{\circ} \mathrm{C} .\right)\end{array}$ & $\begin{array}{c}\text { No. } \\
\text { Patients Tested }\end{array}$ & $\begin{array}{c}\text { Proteinuria } \\
\text { Confirmed }\end{array}$ \\
\hline $37 \cdot 2-38 \cdot 3$ & 62 & 0 \\
$38 \cdot 4$ or greater & 136 & 11 \\
\hline Total & 198 & 11 \\
\hline
\end{tabular}

Table III provides data on the 11 patients with proteinuria. Fever was due to a variety of causes. Ages ranged from 7 months to 16 years and the temperature from $38 \cdot 4-40 \cdot 0^{\circ} \mathrm{C}$. Urine protein concentration was from $30-91 \mathrm{mg} . / 100 \mathrm{ml}$., with a mean of $48 \cdot 5$. A detailed microbiological study was not performed on these patients nor was a consistent treatment schedule followed.

Differential protein clearances were performed on 10 of the 11 patients (Table IV). The $\theta$ angle in 6 patients (over $60^{\circ}$ ) suggested a highly selective proteinuria; in 4 patients it was less than $54^{\circ}$, indicating a poor selectivity (Joachim et al., 1964).

In 3 of the 4 patients with poorly selective proteinuria $\alpha_{2}$-macroglobulin was detected in the urine. An abnormal rise of both serum (1700 mg./ $100 \mathrm{ml}$.) and urine IgG was seen in the fourth patient (Case 7). Two patients (Cases 8 and 9) with $\alpha_{2}$-macroglobulin in the urine had pyuria (8-10 and 15-20 WBC/h.p.f. on a centrifuged specimen). Urine cultures failed to confirm a urinary tract infection in these children.

Of the 11 patients with proteinuria, 4 were retested during subsequent febrile periods a few days to a week after the episode in which proteinuria was detected. The temperature increase was as 
TABLE III

- Clinical and Laboratory Data on Patients with Febrile Proteinuria

\begin{tabular}{|c|c|c|c|c|c|c|c|}
\hline $\begin{array}{l}\text { Case } \\
\text { No. }\end{array}$ & Diagnosis & Age & Sex & $\begin{array}{c}\text { Temperature } \\
\left({ }^{\circ} \mathrm{C} .\right)\end{array}$ & $\begin{array}{l}\text { Urine Protein } \\
\text { Concentration* } \\
\text { (mg./100 ml.) }\end{array}$ & $\begin{array}{l}\text { Urine } \\
\text { Volumet } \\
\text { (mi.) }\end{array}$ & $\begin{array}{c}\text { Total Serum } \\
\text { Protein } \\
\text { (g. } / 100 \mathrm{ml} .)\end{array}$ \\
\hline $\begin{array}{r}1 \\
2 \\
3 \\
4 \\
5 \\
6 \\
7 \\
8 \\
9 \\
10 \\
11\end{array}$ & $\begin{array}{l}\text { Pneumonia } \\
\text { Otitis media } \\
\text { Convulsion and vitamin D deficiency } \\
\text { Upper respiratory infection } \\
\text { Otitis media } \\
\text { Measles } \\
\text { Asthma } \\
\text { CNS sarcoma and flu-like illness } \\
\text { Measles } \\
\text { Pneumonia } \\
\text { Septicaemia }\end{array}$ & $\begin{array}{l}16 \mathrm{yr} . \\
5 \frac{1}{2} \mathrm{yr} . \\
7 \mathrm{mth} \text {. } \\
3 \frac{1}{2} \mathrm{yr} . \\
22 \mathrm{mth} \text {. } \\
4 \mathrm{yr} . \\
6 \frac{1}{2} \mathrm{yr} . \\
11 \mathrm{yr} . \\
4 \mathrm{yr} . \\
9 \frac{1}{2} \mathrm{yr} . \\
3 \frac{1}{2} \mathrm{yr} .\end{array}$ & $\begin{array}{l}\text { M } \\
\mathbf{M} \\
\mathbf{F} \\
\mathbf{F} \\
\mathbf{M} \\
\mathbf{F} \\
\mathbf{F} \\
\mathbf{F} \\
\mathbf{F} \\
\mathbf{M} \\
\mathbf{M}\end{array}$ & $\begin{array}{l}38 \cdot 5 \\
39 \cdot 0 \\
39 \cdot 1 \\
39 \cdot 5 \\
40 \cdot 0 \\
39 \cdot 6 \\
39 \cdot 5 \\
38 \cdot 4 \\
38 \cdot 4 \\
39 \cdot 6 \\
39 \cdot 7\end{array}$ & $\begin{array}{l}91 \\
30 \\
39 \\
64 \\
80 \\
32 \\
49 \\
46 \\
45 \\
47 \\
40\end{array}$ & $\begin{array}{c}150 \\
60 \\
40 \\
54 \\
58 \\
110 / 4 \mathrm{hr} . \\
85 \\
60 \\
40 \\
55 \\
51\end{array}$ & $\begin{array}{l}7 \cdot 55 \\
7 \cdot 24 \\
6 \cdot 94 \\
7 \cdot 20 \\
6 \cdot 64 \\
6 \cdot 42 \\
8 \cdot 40 \\
7 \cdot 30 \\
6 \cdot 34 \\
7 \cdot 41 \\
-\end{array}$ \\
\hline
\end{tabular}

*Sulphosalicylic acid method.

+Single voided specimens except Case 6.

TABLE IV

Urine Protein Selectivity in Patients with Febrile Proteinuria

\begin{tabular}{c|c|c|c}
\hline Case No. & IgG* & $\alpha_{2}$-macroglobulin & $\theta$ Angle \\
\cline { 1 - 3 } 1 & 21 & 0 & $72^{\circ}$ \\
2 & 24 & 0 & $70^{\circ}$ \\
3 & 22 & 0 & $71 \cdot 5^{\circ}$ \\
4 & 22 & 0 & $71 \cdot 5^{\circ}$ \\
5 & 32 & 0 & $66^{\circ}$ \\
6 & 41 & 0 & $60^{\circ}$ \\
7 & 234 & 0 & $1^{\circ}$ \\
8 & 92 & 109 & $10^{\circ}$ \\
9 & 183 & 96 & $2^{\circ}$ \\
10 & 94 & 95 & $8^{\circ}$ \\
\hline
\end{tabular}

$\star \mathrm{U} / \mathrm{S}$ ratio of $\mathrm{IgG}$ (or $\alpha_{2}$-macroglobulin) $\mathrm{U} / \mathrm{S}$ ratio of transferrin

high as or higher than the initial fever in 3 of 4 patients. Proteinuria was absent at this time.

\section{Discussion}

The amount of urinary protein normally excreted is variable. In adults reported values reflect the sensitivity and accuracy of the methods used, with averages from 39-118 mg./24 hours per 1.73 sq.m. (Rigas and Heller, 1951; Berggård, 1961). The upper limit of normal for children is considered to be $75-100 \mathrm{mg}$./24 hours (Garrett, 1967).

Randolph and Greenfield (1967), using a dipstick method, reported a transient proteinuria in $6.3 \%$ of pre-adolescent children tested over a 6 -year period. Some of their patients had an acute illness when proteinuria was detected, however many were apparently well. In our study only $30 \%$ of the urines considered positive by the dipstick method were confirmed to have $30 \mathrm{mg}$./ $100 \mathrm{ml}$. or more of protein by the sulphosalicylic acid method. Thus, though the dipstick method is satisfactory as a screening test (Rennie and Keen 1967), a considerable number of false positives may be encountered (Medical Letter on Drugs and. Therapeutics, 1966).

Normal urine contains proteins of varying molecular weight, in amounts that reflect the relative concentration of these proteins in the serumb (Rowe and Soothill, 1961a). The mechanism of normal proteinuria is not understood but probably depends on the relative rates of protein filtration at the capillary basement membrane and the rate of proximal tubular reabsorption (Sellers, 1956) $\overrightarrow{\vec{R}}$ Proteinuria has been observed in a number of situations in which there is no known renal disease These include exercise (Poortmans and Jeanloz? 1968; Rowe and Soothill, 1961b), changes in postures (Slater, O'Doherty, and DeWolfe, 1960), exposure to cold (Sargent and Johnson, 1956), emotionats stress (Starr, 1926; Ahronheim, 1944), adrenaline. administration (King and Baldwin, 1955), abdominaß operations (Macbeth and Pope, 1968), and fever (Gerhardt, 1869; Schwartz and Kassirer, 19639 Welty, 1937; Ehrström, 1941). Several theories have been proposed to explain the proteinuris. which may be seen with fever. One theory is that an inflammatory response in the kidney resulting from an infectious agent may lead to proteinuriș (Schreiner, 1957; Jensen, 1967; Burch and Sun 1968). However, Welty (1937) showed that evey in the absence of demonstrable infection, feven induced by hyperthermia treatment could lead t $\Phi$ an increased protein excretion. King and Baldwiof (1955) showed that the injection of adrenal medul파 lary hormones might cause transient proteinuria in humans. The effect of these hormones, release $\Phi$ as a result of stress induced by the fever, may be at 
important factor in the development of febrile proteinuria. It is of interest that proteinuria was not detected during a subsequent febrile episode in 4 of the 11 patients with proteinuria during the initial study period. While an explanation for this phenomenon is not at hand, it may reflect the need for a certain specific set of circumstances to obtain in order that the urine protein concentration be high enough to detect (e.g. state of hydration, plasma volume, epinephrine release, renal blood flow). It may also be related to the specific cause of the fever (e.g. one or more particular viral agents), a parameter which was not possible to assess accurately in our study.

The protein excretion pattern is poorly selective in normal subjects (Rowe and Soothill, 1961a), postural proteinuria (Rowe and Soothill, 1961b), and certain forms of renal disease (Soothill, 1962). A more selective pattern is seen in exercise proteinuria (Rowe and Soothill, 1961b), multiple myeloma (Harrison et al., 1966), and the minimal lesion type of the nephrotic syndrome (Soothill, 1962). The 4 patients with poorly selective proteinuria had extremely low $\theta$ angles. A satisfactory explanation for the high IgG/transferrin $U / S$ ratios is not at hand; it is possible that with the techniques employed both intact ( $M W 150,000$ ) and light chain (MW 20,000) urinary IgG molecules were measured in these patients. This might account for the unusual values of the $\theta$ angle observed.

We are indebted to The Kidney Disease Foundation of Canada for their support of Dr. Peter N. McLaine.

\section{Ahronheim, J. H. (1944). Emotional albuminuria. War Medicine, $5,267$.}

Arneil, G. C. (1967). Long term results of intensive steroid therapy of childhood nephrosis. In Proceedings of the 3rd International Congress of Nephrology, Washington 1966, vol. 3, p. 95 . Ed. by E. L. Becker. S. Karger, New York.

Berggárd, I. (1961). Studies on the plasma proteins in normal human urine. Clinica Chimica Acta, 6, 413.

Burch, G. E., and Sun, S. C. (1968). Viral nephritis. American Heart fournal, 75, 1.

Cameron, J. S., and White, R. H. R. (1965). Selectivity of proteinuria in children with the nephrotic syndrome. Lancet, 1, 463.

Canadian Medical Association fournal (1967). Editorial. Management of the nephrotic syndrome due to primary renal disease. 86, 52.

Cipriani, A., and Brophy, D. (1943). A method for determining cerebrospinal fluid protein by the photoelectric colorimeter. fournal of Laboratory and Clinical Medicine, 28, 1269.

Ehrström, M. C. (1941). Ưber febrile Albuminurie. Acta Medica Scandinavica, suppl. 123, 320.

Garrett, J. J. (1967). The interpretation and significance of proteinuria. Missouri Medicine, 64, 111.

Gerhardt, C. (1869). Ueber die Eiweissstoffe de Harnes. Deutsches Archiv für klinische Medizin, 5, 212.

Gornall, A. G., Bardawill, C. J., and David, M. M. (1949). Determination of serum proteins by means of the biuret reaction. fournal of Biological Chemistry, 177, 751.

Hardwicke, J., and Soothill, J. F. (1967). Proteinuria. In Renal Disease, 2nd ed., p. 264. Ed. by D. A. K. Black. Blackwell, Oxford.
Harrison, J. F., Blainey, J. D., Hardwicke, J., Rowe, D. S., and Soothill, J. F. (1966). Proteinuria in multiple myeloma. Clinical Science, 31, 95.

—, Lunt, G. S., Scott, P., and Blainey, J. D. (1968). Urinary lysozyme, ribonuclease, and low-molecular-weight protein in renal disease. Lancet, 1, 371.

Jensen, M. M. (1967). Viruses and kidney disease. American fournal of Medicine, 43, 897.

Joachim, G. R., Cameron, J. S., Schwartz, M., and Becker, E. L. (1964). Selectivity of protein excretion in patients with the nephrotic syndrome. fournal of Clinical Investigation, 43, 2332.

King, S. E., and Baldwin, D. S. (1955). Production of renal ischemia and proteinuria in man with intravenous L-norepinephrine and epinephrine. (Abstr.) Fournal of Clinical Investigation, 34, 945.

__, and Gronbeck, C., Jr. (1952). Benign and pathologic albuminuria: a study of 600 hospitalized cases. Annals of Internal Medicine, 36, 765.

Looney, J. M., and Walsh, A. I. (1939). The determination of spinal fluid protein with the photoelectric colorimeter. fournal of Biological Chemistry, 127, 117.

Macbeth, W. A. A. G., and Pope, G. R. (1968). Effect of abdominal operation upon protein excretion in man. Lancet, 1, 215.

McFarlane, H. (1964). A simple rapid method of concentrating urine for protein electrophoresis. Clinica Chimica Acta, 9, 376.

MacLean, P. R., and Robson, J. S. (1967). A simple method for determining selectivity of proteinuria. Lancet, $1,539$.

Medical Letter on Drugs and Therapeutics (1966). Detection of proteinuria. 8, 103.

Pollak, V. E., Pirani, C. L., Muehrcke, R. C., and Kark, R. M. (1958). Asymptomatic persistent proteinuria: studies by renal biopsies. Guy's Hospital Reports, 107, 353.

Poortmans, J., and Jeanloz, R. W. (1968). Quantitative immunological determination of 12 plasma proteins excreted in human urine collected before and after exercise. Fournal of Clinical Investigation, 47, 386.

Randolph, M. F., and Greenfield, M. (1967). Proteinuria. A sixyear study of normal infants, preschool, and school-age population previously screened for urinary tract disease. American Fournal of Diseases of Children, 114, 631.

Rennie, I. D. B., and Keen, H. (1967). Evaluation of clinical methods for detecting proteinuria. Lancet, 2, 489.

Rigas, D. A., and Heller, C. G. (1951). The amount and nature of urinary proteins in normal human subjects. Fournal of Clinical Investigation, 30, 853.

Rowe, D. S., and Soothill, J. F. (1961a). Serum proteins in normal urine. Clinical Science, 21, 75.

- , and - (1961b). The proteins of postural and exercise proteinuria. Clinical Science, 21, 87.

Sargent, F., II, and Johnson, R. E. (1956). Effects of diet on renal function in healthy men. American fournal of Clinical Nutrition, 4, 466.

Schreiner, G. E. (1957). The differential diagnosis of acute and chronic glomerulonephritis. Fournal of Chronic Diseases, 5, 45.

Schwartz, W. B., and Kassirer, J. P. (1963). Clinical aspects of acute glomerulonephritis. In Diseases of the Kidney, p. 292. Ed. by M. B. Strauss, and L. G. Welt. Little Brown, Boston. Churchill, London.

Sellers, A. L. (1956). The mechanism and significance of protein excretion by the normal kidney. Archives of Internal Medicine, 88,801 .

Slater, R. J., O'Doherty, N. J., and DeWolfe, M. S. (1960). Studies on human proteinuria 1 . The mechanism of postural proteinuria. Pediatrics, 26, 190.

Soothill, J. F. (1962). Studies on proteinuria with special reference to immunochemically determined differential protein clearances. Guy's Hospital Reports, 111, 355.

Starr, I., Jr. (1926). The production of albuminuria by renal vasoconstriction in animals and in man. Fournal of Experimental Medicine, 43, 31.

Welty, J. W. (1937). Febrile albuminuria. American Fournal of the Medical Sciences, 194, 70.

Correspondence to Dr. K. N. Drummond, Director, Renal Laboratory, Montreal Children's Hospital, 2300 Tupper Street, Montreal, Canada. 